\title{
METABOLISM OF SALT-RETAINING HORMONE BY SURVIVING LIVER SLICES ${ }^{1}$
}

\author{
By JEROME J. CHART, ${ }^{2}$ EDGAR S. GORDON, PHYLLIS HELMER, AND \\ MARJORIE LE SHER \\ (From the Departments of Medicine and Zoology, University of Wisconsin, Madison, Wis.)
}

(Submitted for publication June 14, 1955; accepted October 17, 1955)

Evidence has been produced in this and other laboratories that the impaired capacity to excrete sodium which characterizes a number of clinical states involving edema, ascites and anasarca, is mediated, in part at least, through a humoral factor emanating, in all probability, from the adrenal cortex (1-8). It now appears almost certain, on the basis of available evidence, that this substance, generally referred to in this paper as salt-retaining hormone or electrocortin, is aldosterone or a derivative of it $(9,10)$.

Since quantitative measurements indicate that this sodium-retaining hormone is excreted in the urine in abnormally high concentration under these pathological conditions, curiosity concerning the underlying mechanism naturally arises. Two hypothetical possibilities are suggested: 1 . Overproduction of salt-retaining hormone by the adrenal cortex initiates an abnormal anti-natriuretic and antidiuretic response. 2. Physiological inactivation or metabolism of the hormone by extra-adrenal tissues is impaired with a resulting rise in blood, tissue and urine concentrations of "active" hormone. However, it is possible that accumulation of salt-retaining hormone, whatever its cause, bears no cause and effect relationship to fluid retention and other related manifestations of disease.

In view of the recent evidence by Conn $(11,12)$ and Mader and Iseri (13) consideration must be given to the first of these possibilities. "Primary aldosteronism," a new syndrome described by these investigators, is characterized by hyperna-

1 This work has been supported in part by funds provided by the Smith, Kline and French Laboratories of Piviadelphia, and also by grants from the Wisconsin ITrart Association, and the Johnson Foundation, Racine, Wisconsin. It was also supported in part by the Research Committee of the Graduate School from funds supplied by the Wisconsin Alumni Research Foundation.

2 Present address: CIBA Pharmaceutical Products, Inc., Summit, New Jersey. tremia and hypokalemia, but not necessarily edema. In this condition an adrenal tumor has been found which appeared to be secreting large quantities of aldosterone. It is doubtful, however, if adrenal cortical hyperfunction of this type can be indicted as a frequent cause of the high levels of sodiumretaining factor found in various pathologic states in which sodium retention and edema are characteristically seen. In toxemias of pregnancy the rapid fall in the urinary titer following delivery would suggest that high aldosterone levels derive from some transient derangement of functional control in contrast to the apparently continuous hyperfunction found in primary aldosteronism. Also, evidence of adrenal cortical hyperfunction is not a consistent finding in hepatic cirrhosis, congestive heart failure and nephrosis, diseases in which salt retention, edema, and high urinary aldosterone levels are characteristic $(3,7,14)$. That there is a cause and effect relationship, however, between the abnormal accumulation of fluid and sodium retention in cirrhosis of the liver, congestive heart failure and toxemia of pregnancy is suggested by the now well recognized importance of dietary salt restriction in retarding or preventing edema and ascites in these conditions.

In an attempt to obtain further evidence bearing on the second hypothesis, the capacity for in vitro inactivation of this salt-retaining factor by surviving liver slices has been studied, and the results, previously reported in abstract form (15), are presented in this communication.

\section{EXPERIMENTAL}

Twenty-four-hour urine collections from patients with cirrhosis of the liver, congestive heart failure and preeclamptic toxemia provided the active salt-retaining material. This urine was stored in the refrigerator without preservative and extracted within twenty-four hours. Extraction with chloroform followed hydrolysis at $\mathrm{pH} 1$ (sulfuric acid) overnight at room temperature, according to a standard procedure previously published 
(2). The final extract, which contains all active adrenal steroid compounds with the exception of estrogens and androgens, was then partitioned in a benzene-water system. Under these conditions, the sodium-retaining activity moves along with cortisone and hydrocortisone into the water phase, while a number of contaminating compounds including a large amount of pigment, are removed in the benzene phase. Most of the extracts were then subjected to partition chromatography in a toluene-propylene glycol system on filter paper according to the general scheme of Zaffaroni and Burton (16). Under these conditions the bands of compounds $\mathrm{F}$ and $\mathrm{E}$ are widely separated with the latter moving 10 to $12 \mathrm{~cm}$. farther. The papers were then divided into three sections by cutting below the compound $F$ band and below the compound $\mathrm{E}$ band, the sections were eluted with an absolute methanol-chloroform mixture and the eluates evaporated to dryness. The eluates were assayed for sodium-retaining activity according to the method of Kagawa, Shipley, and Meyer (17). The active sodiumretaining fraction was consistently found in close association with the cortisone band. Potency was recorded in terms of percentage of sodium retained per unit of extract, under the specific experimental conditions of the assay.
The active extracts of known potency were then dissolved in small amounts of absolute ethanol and incubated with surviving rat liver slices for two hours in $15-\mathrm{ml}$. Warburg flasks at 37 degrees Centigrade. Krebs-Ringerphosphate buffer was employed as the incubation medium and the flasks contained potassium hydroxide in the center well. Fifty to sixty-milligram liver slices (wet weight) were used per flask and the active extract in ethanol was prepared so that an adequate dose for five assay animals was contained in $0.1 \mathrm{ml}$. Respiration was measured and $\mathrm{QO}_{2}$ values were calculated. Control flasks were prepared containing no tissue, boiled tissue, and to others 0.01 molar cyanide was added. In several instances anaerobic incubation was carried out using bicarbonate buffer in an atmosphere of nitrogen. Kidney slices were also studied by the same technique and, in addition, one experiment was performed with human liver, using tissue obtained at laparotomy from a patient with no evidence of liver or endocrine disease, and without any suggestion of a disorder in either fluid or electrolyte balance.

At the end of the incubation period, contents of the flasks were re-extracted with chloroform, and the resulting extracts re-assayed under experimental condi-

TABLE I

Sodium retaining activity of urine extracts after incubation with rat and human liver slices *

\begin{tabular}{|c|c|c|c|c|c|c|c|c|c|}
\hline $\begin{array}{l}\text { Experiment No. } 1 \\
\text { Extract MH }\end{array}$ & $\begin{array}{l}\text { Oil } \\
\text { control }\end{array}$ & $\begin{array}{l}\text { Untreat. } \\
\text { extract }\end{array}$ & Liver & $\begin{array}{c}\text { Cyanide } \\
\text { liver }\end{array}$ & $\begin{array}{c}\text { Boiled } \\
\text { liver }\end{array}$ & $\begin{array}{c}\text { No } \\
\text { tissue }\end{array}$ & Kidney & $\begin{array}{c}\text { Anaerobic } \\
\text { liver }\end{array}$ & $\begin{array}{l}\text { Cyan. } \\
\text { No tiss. }\end{array}$ \\
\hline $\begin{array}{l}\text { Sodium exc. mg. } \\
\text { Stand. error } \\
\text { "t" } \\
\text { Per cent act. }\end{array}$ & $\begin{array}{l}2.42 \\
0.23 \\
3.04 \uparrow\end{array}$ & $\begin{array}{l}1.66 \\
0.14 \\
100\end{array}$ & $\begin{array}{l}2.53 \\
0.26 \\
3.27 \dagger \\
0\end{array}$ & $\begin{array}{c}2.67 \\
0.70 \\
2.3 \ddagger \\
0\end{array}$ & $\begin{array}{r}1.54 \\
0.26 \\
0.14 \\
100\end{array}$ & $\begin{array}{l}1.74 \\
0.23 \\
0.1 \\
90\end{array}$ & $\begin{array}{r}1.79 \\
0.23 \\
0.53 \\
83\end{array}$ & & \\
\hline
\end{tabular}

\begin{tabular}{|c|c|c|c|c|c|c|c|c|c|}
\hline \multicolumn{10}{|l|}{$\begin{array}{c}\text { Experiment No. } 2 \\
\text { Extract OS }\end{array}$} \\
\hline $\begin{array}{l}\text { Sodium exc. mg. } \\
\text { Stand. error } \\
\text { " } t \text { " } \\
\text { Per cent act. }\end{array}$ & $\begin{array}{l}2.6 \\
0.22 \\
8.23 \dagger\end{array}$ & $\begin{array}{l}0.87 \\
0.1 \\
100\end{array}$ & $\begin{array}{l}3.35 \\
0.34 \\
9.92 \dagger \\
0\end{array}$ & $\begin{array}{l}2.53 \\
0.34 \\
6.26 \dagger \\
\quad 4\end{array}$ & $\begin{array}{l}1.1 \\
0.27 \\
0.98 \\
87\end{array}$ & $\begin{array}{r}0.81 \\
0.13 \\
0.29 \\
100\end{array}$ & $\begin{array}{r}0.84 \\
0.03 \\
0.15 \\
100\end{array}$ & $\begin{array}{l}1.87 \\
0.59 \\
2.98 \dagger \\
42\end{array}$ & \\
\hline \multicolumn{10}{|l|}{$\begin{array}{c}\text { Experiment No. } 3 \\
\text { Extract P-83 }\end{array}$} \\
\hline $\begin{array}{l}\text { Sodium exc. mg. } \\
\text { Stand. error } \\
\text { " } t \text { " } \\
\text { Per cent act. }\end{array}$ & $\begin{array}{l}2.6 \\
0.22 \\
7.74 \dagger\end{array}$ & $\begin{array}{r}0.85 \\
0.16 \\
100\end{array}$ & $\begin{array}{l}2.3 \\
0.14 \\
6.41 \dagger \\
17\end{array}$ & $\begin{array}{l}2.2 \\
0.34 \\
4.93 \dagger \\
23\end{array}$ & $\begin{array}{r}1.06 \\
0.12 \\
1.21 \\
88\end{array}$ & $\begin{array}{r}0.71 \\
0.12 \\
0.62 \\
100\end{array}$ & & $\begin{array}{l}2.2 \\
0.24 \\
6.0 \dagger \\
23\end{array}$ & $\begin{array}{l}2.05 \\
0.05 \\
5.47 \dagger \\
31\end{array}$ \\
\hline $\begin{array}{c}\text { Experiment No. } 4 \\
\text { Extract P-83 }\end{array}$ & \multicolumn{2}{|c|}{$\underset{\text { liver }}{\text { Human }}$} & \multicolumn{2}{|c|}{$\begin{array}{c}\text { Boiled } \\
\text { human } \\
\text { liver }\end{array}$} & \multicolumn{2}{|c|}{$\begin{array}{c}\text { Anaerobic } \\
\text { human } \\
\text { liver }\end{array}$} & & & \\
\hline $\begin{array}{l}\text { Sodium exc. mg. } \\
\text { Stand. error } \\
\text { "t" } \\
\text { Per cent act. }\end{array}$ & \multicolumn{2}{|c|}{$\begin{array}{c}2.37 \\
0.19 \\
7.6 \dagger \\
13\end{array}$} & \multicolumn{2}{|c|}{$\begin{array}{l}0.76 \\
0.1 \\
0.41 \\
100\end{array}$} & \multicolumn{2}{|c|}{$\begin{array}{l}1.51 \\
0.35 \\
2.46 \ddagger \\
62\end{array}$} & & & \\
\hline
\end{tabular}

* The values shown in the "Sodium Excretion" column are the average values in milligrams of sodium excreted by groups of rats receiving urine extracts which had been subjected to the various treatments indicated. Retention or excretion of sodium can readily be determined by comparing any of the values to the corresponding figures for the "oil control" group.

$+\mathrm{P}<0.01$.

$\ddagger \mathrm{P}<0.05$. 


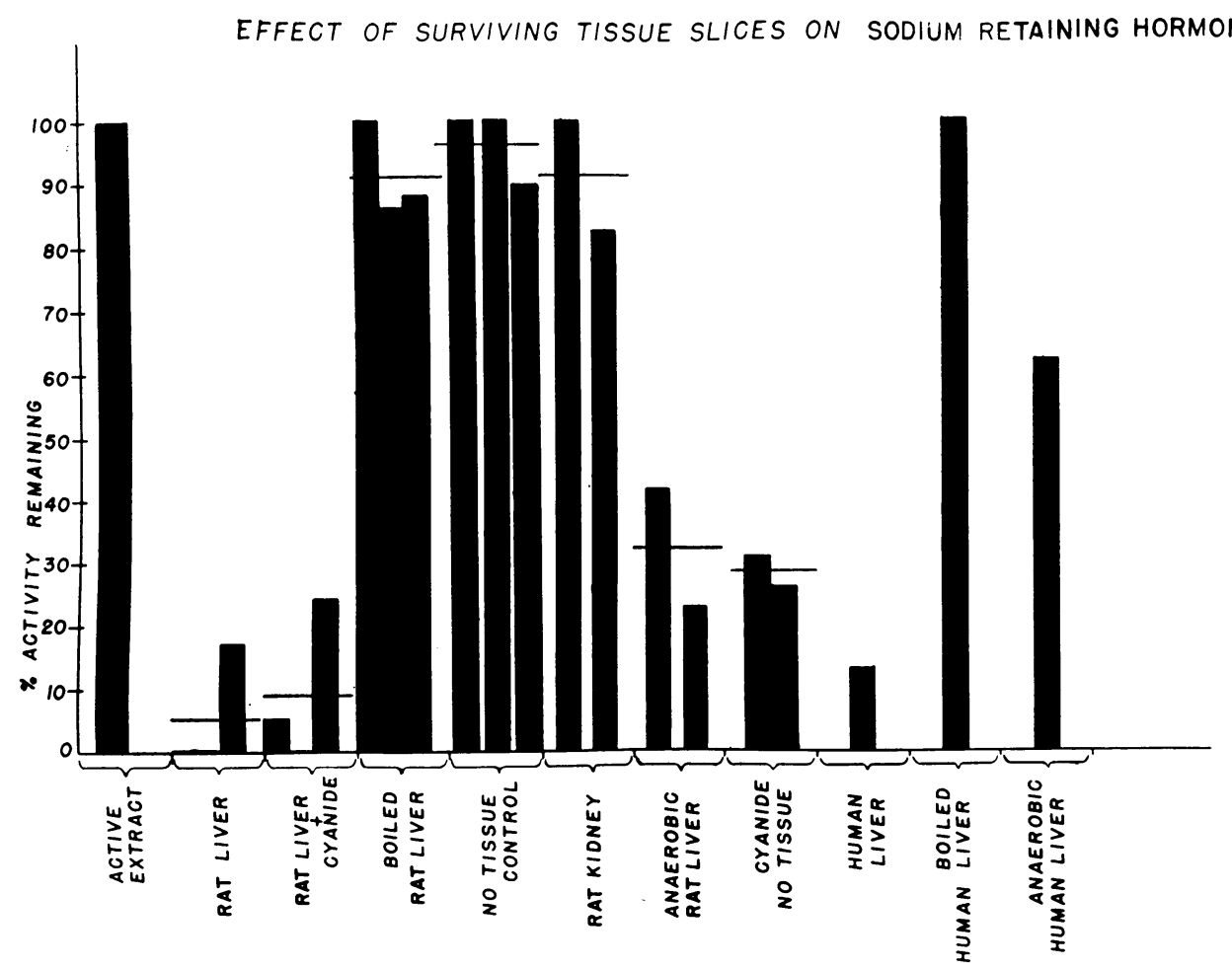

FIGLRE 1

tions as nearly identical as possible to the pre-incubation measurements.

\section{RESULTS}

Extracts from three different subjects (designated as $\mathrm{MH}$, OS and P-83) were incubated with liver tissue. A summary of results obtained from bioassay of these extracts after incubation is shown in Table I. To test for significant differences between the various treatments, the sodium excretion values were subjected to Fisher's "t" test as described by Snedecor (18). In all cases the " $\mathrm{t}$ " values listed for the various groups were obtained by using the sodium excretion found in response to untreated extract as the basis for comparison. In contrast to the oil control animals, the decrease in sodium excretion by animals receiving the untreated extract was highly significant. The " $\mathrm{t}$ " values for this comparison are shown in the "Oil Control" column. The relative activity of the sodium-retaining factor after being subjected to the various treatments indicated is tabulated in the "per cent activity" column. The sodium retention exhibited by the untreated extracts is arbitrarily designated as 100 per cent activity, and the retention found in response to the treated extracts is expressed as a percentage of that manifested by the untreated extracts. In some instances it is apparent that more sodium was excreted by groups of animals treated with incubated extracts than was observed in the "Oil control" group. This is interpreted to mean that complete inactivation of the sodium-retaining compound had taken place, but an explanation of the sodium excreting activity of these extracts needs further investigation and lies beyond the scope of this paper. Therefore, in this report, these extracts inducing sodium excretion are considered to contain 0 per cent activity.

Surviving, actively-respiring liver slices caused, in every instance, complete or nearly complete loss of sodium-retaining activity in the post-incubation extracts. Boiled liver slices, on the other hand, produced no significant inactivation. Addition of 0.01 M cyanide invariably produced very great inactivation, which, in some experiments was complete. In the anaerobic system incomplete but significant inactivation was noted with both the rat 
and human liver slices. The data suggest that these conditions may impair the inactivating capacity of liver tissue. The decreased inactivation of sodium-retaining factor by human liver incubated anaerobically is statistically significant when compared to aerobic incubation. Kidney slices failed to produce inactivation of importance in two experiments.

Figure 1 presents these data in the form of a bar graph. The activities remaining after the various treatments are calculated as percentages of the corresponding untreated extracts, and are so represented in the histogram. For example, after incubation with normal liver, extracts $\mathrm{MH}, \mathrm{OS}$ and P-83 show 0 per cent, 0 per cent, and 17 per cent activities, respectively, as compared to their unincubated controls. Mean values are designated by horizontal lines.

\section{DISCUSSION}

In common with several other steroid compounds that have been studied, the salt-controlling hormone of the adrenal cortex (considered to be aldosterone) appears to be metabolized and partially inactivated by extra-adrenal tissues, especially the liver. This mechanism has been shown to function in the case of cortisone by Eisenstein (19) and for cortisone and hydrocortisone by Schneider and Horstmann (20), by Conn, Fajans, Louis, and Seltzer (21), by Bongiovanni and Eisenmenger (22) and by Tyler and his associates (23-25). Similar metabolic effects of the liver on estrogens have been demonstrated by Fishman (26), by Heller (27), by Ryan and Engel $(28,29)$, and by numerous others $(30,31)$. In the case of testosterone, Wotiz, Lemon, and Voulgaropoulos $(32,33)$ have reported similar enzymatic transformations. Hepatic inactivation of aldosterone may be regarded, therefore, as an additional instance of a recognized pattern, and, we believe, may represent an important physiological control mechanism which supplements the fluctuating levels of discharge from the adrenal gland to regulate the amount of circulating "active hormone."

The data from this investigation suggest that anaerobic conditions in vitro tend to impair somewhat the otherwise high efficiency of hepatic enzymes for inactivation of the salt-retaining hor- mone, although this action does not appear to be entirely destroyed. It is tempting to speculate concerning the possible role of hypoxia of the liver in congestive heart failure as a contributing factor in bringing about the elevated urinary level of salt-retaining hormone which has already been demonstrated in this disease.

Addition of $0.01 \mathrm{M}$ cyanide to the incubation

QUANTITATIVE RESPONSE TO INTRAVENOUS ACTH IN VARYING DOSAGE
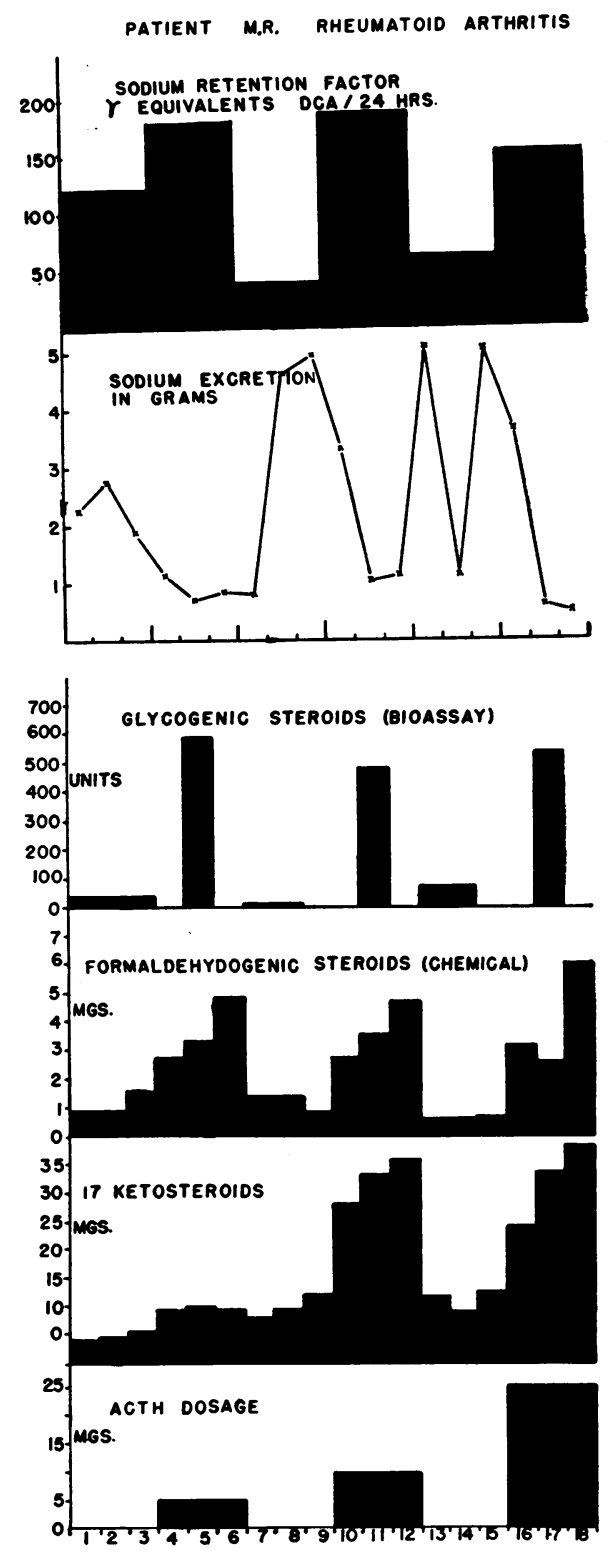

FIGURE 2 
preparation, completely inhibited all respiratory activity as anticipated, but the decrease in sodiumretaining potency which followed was nearly as great as that produced by intact respiring liver slices. This result became somewhat clarified when incubation of the extract with cyanide in phosphate buffer, without tissue, also produced approximately the same degree of inactivation. It is apparent that some chemical reaction, between cyanide and the sodium-retaining compound, not dependent upon enzymatic activity, is capable of destroying the biological activity of the steroid hormone.

The means of regulation of adrenal cortical production and release of electrolyte-controlling hormone remain obscure but it appears increasingly clear that it is not entirely under the control of pituitary ACTH, as are the glycogenic corticoids $(34,35)$. Our own studies, as illustrated in Figure 2, have demonstrated a slight rise in urinary titer of sodium-retaining activity in response to intensive ACTH stimulation, when the hormone is administered by slow intravenous drip over a period of three days. It is quite possible that this small change is related to other steroid compounds produced by the adrenal cortex under ACTH control, such as corticosterone (Compound B). Liddle, Cornfield, Casper, and Bartter (36) have also found the sodium-retaining activity of chromatographed urine extracts of patients receiving $\mathrm{ACTH}$ to be increased approximately two-fold and in these experiments, the rise is presumably attributable specifically to aldosterone. In either case, however, these values do not approach the exceedingly high titers that are found so regularly under pathological conditions of salt and water retention. It seems more likely, therefore, that aldosterone release must depend upon total body reserves of sodium and/or potassium, or upon absolute osmolarity of blood and interstitial fluid. It has even been proposed that some other pituitary trophic hormone, as for example the growth hormone, might serve as the regulatory mechanism, but this hypothesis seems unlikely since the urinary titers of salt-retaining activity in panhypopituitarism are found to be within approximately the normal range $(2,34)$.

Tyler, Samuels, and their co-workers (23-25) have proposed that hepatic inactivation of hydro- cortisone may be of great importance as a supplementary mechanism, in explaining the variations in blood 17-hydroxycorticosteroid levels occurring both in the "steady state" and under conditions of stress. In accordance with this view, the evidence from the present study suggests the possibility that aldosterone likewise may accumulate in abnormal amounts in disease states as a result of decreased liver inactivation as well as increased adrenal production and release.

The adrenal cortex is currently regarded as an organ primarily concerned with homeostasis of the internal environment. For the purpose of effecting this complex type of physiological control, the gland is capable of releasing several steroid compounds into the blood stream, each possessing specialized and characteristic biological effects. The over-all hormonal response to the adrenal secretion in the intact animal may therefore be expected to be an algebraic summation of the individual actions of its active components. Metabolic modification of all of these compounds by the liver, under a wide variety of environmental conditions may represent an additional refinement of the control mechanism to the end of preventing an abnormal accumulation of biologically potent hormones. Viewed against this background, the increased amounts of salt-retaining hormone occurring in edematous states may be interpreted either as an unfortunate consequence of impaired liver function, or as a continually acting compensatory mechanism directed toward the homeostasis of electrolyte and osmolarity conditions in the circulation, in the face of pathological factors which cause a continuous loss of sodium and water into the extra-vascular space. Thus control receptors in the circulation might fail to be activated and adrenal over-production of aldosterone would be superimposed upon impaired hepatic inactivation as a cause of abnormal sodium retention by the kidney. Choice between these two hypotheses is impossible on the basis of present experimental evidence.

\section{CONCLUSIONS}

1. Surviving, actively respiring rat liver slices incubated with urinary sodium-retaining factor (aldosterone) are capable of completely inactivating the biological potency of the hormone. 
2. Anaerobic conditions impair this inactivating capacity of liver slices.

3. Kidney slices produce insignificant inactivation of the salt-retaining hormone.

4. Under these experimental conditions, human liver slices manifest a capacity for inactivation of salt-retaining hormone similar to that of rat tissues.

5. Hepatic inactivation and removial of "active" steroid hormones, including aldosterone, may serve as a supplementary homeostatic mechanism, a derangement of which, through impaired liver function, may lead to abnormal accumulation of hormone in blood, tissues and urine.

\section{REFERENCES}

1. Chart, J. J., Shipley, E. G., and Gordon, E. S., Evidence for a sodium retaining factor in toxemia of pregnancy. Proc. Soc. Exper. Biol. \& Med., 1951, 78, 244.

2. Gordon, E. S., Chart, J. J., Hagedorn, D., and Shipley, E. G., Mechanism of sodium retention in preeclamptic toxemia. Obst. \& Gynec., 1954, 4, 39.

3. Luetscher, J. A., Jr., Deming, Q. B., and Johnson, B. B., The sodium-retaining activity of the corticoid fraction of urine of oedematous patients. Ciba Foundation Colloquia on Endocrinology, G. E. W. Wolstenholme, Ed., London, J. \& A. Churchill, 1952, vol. 4, p. 530.

4. Luetscher, J. A., Jr., Deming, Q. B., and Johnson, B. B., Treatment of nephrosis with pituitary adrenocorticotrophin. J. Clin. Invest., 1951, 30, 1530.

5. Merrill, A. J., Mechanisms of salt and water retention in heart failure. Am. J. Med., 1949, 6, 357.

6. Goodyer, A. V. N., Relman, A. S., Lawrason, F. D., and Epstein, F. H., Salt retention in cirrhosis of the liver. J. Clin. Invest., 1950, 29, 973.

7. Chart, J. J., and Shipley, E. S., The mechanism of sodium retention in cirrhosis of the liver. J. Clin. Invest., 1953, 32, 560.

8. Gaunt, R., Renzi, A. A., and Chart, J. J., Aldosterone -a review. J. Clin. Endocrinol., 1955, 15, 621.

9. Simpson, S. A., Tait, J. F., Wettstein, A., Neher, R., v. Euw, J., Schindler, O., and Reichstein, T., Konstitution des Aldosterons, des neuen Mineralocorticoids. Experientia, 1954, 10, 132.

10. Luetscher, J. A., Jr., Neher, R., and Wettstein, A., Isolation of crystalline aldosterone from the urine of a nephrotic patient. Experientia, 1954, 10, 456.

11. Conn, J. W., Presidential address. Part I. Painting background. Part II. Primary aldosteronism, a new clinical syndrome. J. Lab. \& Clin. Med., 1955, $45,3$.

12. Conn, J. W., Progress report: primary aldosteronism. J. Lab. \& Clin. Med., 1955, 45, 661.
13. Mader, I. J., and Iseri, L. T., Am. J. Med. (in press).

14. Singer, B., and Wener, J., Excretion of sodium-retaining substances in patients with congestive heart failure. Am. Heart J., 1953, 45, 795.

15. Gordon, E. S., Inactivation of salt-retaining hormone by liver. J. Lab. \& Clin. Med., 1954, 44, 803.

16. Zaffaroni, A., and Burton, R. B., Identification of corticosteroids of beef adrenal extract by paper chromatography. J. Biol. Chem., 1951, 193, 749.

17. Kagawa, C. M., Shipley, E. G., and Meyer, R. K., A biological method for determining small quantities of sodium retaining substances. Proc. Soc. Exper. Biol. \& Med., 1952, 80, 281.

18. Snedecor, G. W., Statistical Methods. Applied to Experiments in Agriculture and Biology. Ames, The Iowa State College Press, 1946.

19. Eisenstein, A. B., Steroid compounds resulting from incubation of cortisone with surviving liver slices. J. Lab. \& Clin. Med., 1952, 40, 796.

20. Schneider, J. J., and Horstmann, P. M., Effects of incubating compound $\mathrm{E}$ and related steroids with various surviving rat tissues. J. Biol. Chem., 1952, 196, 629.

21. Conn, J. W., Fajans, S. S., Louis, L. H., and Seltzer, $\mathrm{H}$. S., Importance of the liver in transformations of administered adrenosteroidal compounds. J. Lab. \& Clin. Med., 1954, 43, 79.

22. Bongiovanni, A. M., and Eisenmenger, W. J., Adrenal cortical metabolism in chronic liver disease. J. Clin. Endocrinol., 1951, 11, 152.

23. Tyler, F. H., Schmidt, C. D., Eik-Nes, K., Brown, H., and Samuels, L. T., The role of the liver and the adrenal in producing elevated plasma 17-hydroxycorticosteroid levels in surgery. J. Clin. Invest., 1954, 33, 1517.

24. Brown, H., Willardson, D. G., Samuels, L. T., and Tyler, F. H., 17-Hydroxycorticosteroid metabolism in liver disease. J. Clin. Invest., 1954, 33, 1524.

25. Sandberg, A. A., Eik-Nes, K., Samuels, L. T., and Tyler, F. H., The effects of surgery on the blood levels and metabolism of 17-hydroxycorticosteroids in man. J. Clin. Invest., 1954, 33, 1509.

26. Fishman, W. H., Relationship between estrogens and enzyme activity. Vitamins and Hormones, 1951, 9, 213.

27. Heller, C. G., Metabolism of the estrogens. The effect of liver and uterus upon estrone, estradiol and estriol. Endocrinology, 1940, 26, 619.

28. Ryan, K. J., and Engel, L. L., The interconversion of estrone and estradiol-17 $\beta$ by rat liver slices. Endocrinology, 1953, 52, 277.

29. Ryan, K. J., and Engel, L. L., The interconversion of estrone and estradiol by human tissue slices. Endocrinology, 1953, 52, 287.

30. Lloyd, C. W., and Williams, R. H., Endocrine changes associated with Laennec's cirrhosis of the liver. Am. J. Med., 1948, 4, 315.

31. Evans, J. M., Young, J. P., Hertz, R., Tullner, W. W., Wilmer, G., and Wood, O., The ability of the 
human liver to reduce the biologic activity of injected estrogens. J. Clin. Endocrinol., 1952, 12, 495.

32. Wotiz, H. H., Lemon, H. M., and Voulgaropoulos, A., Studies in steroid metabolism. II. Metabolism of testosterone by human tissue slices. J. Biol. Chem., 1954, 209, 437.

33. Wotiz, H. H., Lemon, H. M., and Voulgaropoulos, A., Metabolism of testosterone by human tissues. Federation Proc., 1954, 13, 325.

34. Luetscher, J. A., Jr., and Axelrad, B. J., Sodiumretaining corticoid in the urine of normal children and adults and of patients with hypoadrenalism or hypopituitarism. J. Clin. Endocrinol., 1954, 14, 1086.

35. Farrell, G. L., Royce, P. C., Rauschkolb, E. W., and Hirschmann, H., Isolation and identification of aldosterone from adrenal venous blood. Proc. Soc. Exper. Biol. \& Med., 1954, 87, 141.

36. Liddle, G. W., Cornfield, J., Casper, A. G. T., and Bartter, F. C., Acute renal response to aldosterone: physiological basis for a new assay method. (Abstract) Program of the 37th Meeting of the Endocrine Society, Atlantic City, June 2-4, 1955. 